Georgia State University

ScholarWorks @ Georgia State University

$12-2019$

\title{
Lost in the Park: Learning to Navigate the Unpredictability of Fieldwork
}

\author{
Elizabeth Bonomo \\ Northern Arizona University \\ Scott Jacques \\ Georgia State University
}

Follow this and additional works at: https://scholarworks.gsu.edu/cj_facpub

Part of the Criminology and Criminal Justice Commons

\section{Recommended Citation}

Bonomo, Elizabeth, and Scott Jacques. 2019. Lost in the Park: Learning to Navigate the Unpredictability of Fieldwork. Chapter 2 in Inside Ethnography: Narratives of Research among Hidden Populations, eds. Rashi Shukla and Miriam Boeri. Berkeley and Los Angeles, CA: University of California Press.

This Book Chapter is brought to you for free and open access by the Department of Criminal Justice and Criminology at ScholarWorks @ Georgia State University. It has been accepted for inclusion in CJC Publications by an authorized administrator of ScholarWorks @ Georgia State University. For more information, please contact scholarworks@gsu.edu. 


\section{Introduction}

At a park in downtown Atlanta, there is an area about the size of a boxing ring where people gather to play chess. Surrounded by low perching walls with flower boxes on top, there are four picnic style tables with inlay chessboards. Across the street are restaurants, coffee shops, business offices, Georgia State University (GSU), and a police precinct. During the day, the area is bustling with activity. The chess players make moves, watch games, socialize, drink alcohol, smoke marijuana, gamble, and hustle.

Though the chess park may sound nice, students and professionals considered it to be a "no go" zone inside an otherwise open city center. They walked next to the chess park on their way to class or work, but stayed to themselves. In part, this avoidance was due to perceiving the players as homeless, which they often were. They were usually dirty, and many carried large bags with all of their belongings. Students report feeling "uneasy and anxious" when near the players because they are "homeless and crazy," so they "might stop you and rob you."

I (Liz) began researching the chess park while taking Scott's ${ }^{1}$ qualitative research methods course during my third year of graduate school at GSU. The course required us to ethnographically study a stigma of our choice (see Goffman, 1963). Over the prior semesters, I had become interested in the chess park and players. My curiosity stemmed, in part, from an invisible line dividing passersby and the players. They were a visible fixture of the downtown Atlanta scene, but deliberately not seen by most pedestrians.

This perception of the players as "homeless" was what I originally intended to study as the stigma. My thinking was people were scared of the players because they seemed homeless (see also Snow \& Anderson, 1993). However, there was another important characteristic of the players: they were black. Passing observers cast the players as dangerous and criminal 
(Anderson, 1999, 2011; Duneier, 1999). The players, then, were not only stigmatized because they appear to be homeless, but also because they were black males.

This chapter describes my experience researching the chess players. The project lasted a couple years, was supervised by Scott, and approved by GSU's IRB. By the end, I learned why they go to the park, what they do there, how they perceive themselves to be perceived by passersby, how that affects them, and their identities in and outside the park. That knowledge was a long time in the making, with many stumbling blocks along the way. This chapter discusses the problems I faced and how they were resolved during the course of my ethnographic study at the park.

\section{First Move}

There are a variety of ways to access data and produce a sample (see Boeri \& Lamonica, 2015). There is no one right way to generate cases because what is best depends on the population's characteristics and the ethnographer's resources (e.g., preexisting contacts, research monies). In my case, the players were not a "hidden population" and I had no preexisting ties to them (on how these factors affect sampling, see Copes, Jacques, Hochstetler, \& Dickinson, 2015). Thus, the obvious path was to introduce myself to the players and then observe and speak with them.

Gaining access to such a group may seem simple, yet actually doing so can be quite difficult (e.g., Bernasco, 2010; Copes \& Miller, 2015; Miller \& Palacios, 2015). While it was clear how I should approach the scene, the same was not true of how exactly to do so. The most straightforward approach would be to walk up, identity myself as a researcher, briefly describe what I want to know, and ask for their participation. Scott thought that would work fine because he had done so for his own research on other populations, plus he figured the players would 
welcome interaction with a young lady. But I was apprehensive. I had convinced myself it was "their" park and it belonged to them. I viewed myself as an intruder and did not think I could just walk up to them and start asking them questions.

Instead, I wanted to covertly gain access. This approach requires the researcher to hide their true identity and intentions from the subjects. The researcher must develop a cover story, or plausible justification, for their ongoing presence in the setting while they secretly conduct their study. I felt it was unrealistic for me to be forthright with my study intentions, as overt research would have required. I assumed they would be wary of me entering "their" space and reluctant toward participating in the study. Additionally, I lacked confidence in my ability as a researcher and felt a sense of comfort in covertly approaching them. In some ways, it allowed me to put my doubt aside and focus on the role I needed to play to keep my cover in the field. I hoped to establish rapport with the players and in turn, gain their permission to talk in-depth about my research interests.

Covert work requires a plausible cover story (Marx, 1989). Thus, I had to come up with an identity that the players would accept as a legitimate reason for me to be at the park. ${ }^{2}$ This was made all the more difficult because my appearance prevented me from simply "fitting in" based on looks alone. I am female, white, and have a style that is the antithesis of "street." Such differences between observer and observed make covert work more difficult.

I had little control over how I looked, so the cover story would have to be especially convincing. Given that chess is the foundational activity of the scene, one approach would be for me to sell myself as a chess player looking for a game. The problem with that idea is I did not know how to play. So, instead, I came up with the following idea for making contact. At a predetermined day and time, I would go to the park, say hello to some players, and start a 
conversation. When the planned time came, I went to the park but I only had the courage to sit on the outside looking in, close enough to see but not hear what was going on. My anxiety stemmed from me feeling like an intruder.

The next day, I went into Scott's office to ask for advice on how to make headway. We decided that simply going to the park to have a conversation was an inadequate cover story. In truth, I later learned that this would not have been wholly implausible, albeit potentially problematic for another reason. Fast forwarding a bit, once I had gained a place at the park (discussed below), many of the players thought I was a "snow bunny," defined by them as a white female who wants relations with black men (see also Goffman, 2014). Nonetheless, that approach to gaining access would have been troubled. It could cause conflicts with players should they feel disrespected by being turned down by me, or jealous of those they think are with me. Also, using sex (appeal) to gain access is considered unethical in some circles, as is having an intimate relationship with a participant (see Goode, 1999).

Scott and I decided that since I did not know how to play chess, the next best option was to ask for lessons. The cover story was to pass as someone who wanted to learn chess and was solely there to get lessons. Not knowing how to play made it easier to pretend because I was learning in real time. In addition, a part of me was interested in learning the game for learning's sake. However, this was largely overshadowed by my research intentions. Nevertheless, because there was an element of truth to this identity, that I had an interest in learning the game, we hoped it would reduce my anxiety about approaching the players.

I went back to the park a few days later and stood at the perimeter, observing and slowly building up my confidence to approach the men and ask for a lesson. On that particular day, there were two book vendors set up near the border of the park. I decided to stop by their table 
since it would bring me closer to the players. I made small talk with the vendors for a few minutes, but I was stalling. I was worried about how the players would respond, not sure if they would be willing to give me lessons. This was a defining moment for my fieldwork, and I did not want to mess up. After some minutes passed, I walked up to the nearest table and awkwardly blurted out, "So, who's gonna teach me how to play chess?" I stood there, looking at the players and hoping they would say something. To my surprise, without much hesitation, they started shouting, "Alvin! Alvin!"3

\section{Pay to Play}

The players seemed excited as they were saying Alvin's name. They assured me he was the best at chess and therefore, he needed to be the one to teach me. I stood there as they got his attention and he made his way over to where I was standing. It happened quickly and I remember feeling relived that they were being so receptive toward me.

As Alvin made his way over, the group informed him what was going on and he agreed to give me a lesson. He said he could teach me but it would cost $\$ 5$ upfront. I did not have cash on me, but I assured him I would pay him afterwards. He refused. This took me by surprise in the moment, but in hindsight, it was silly of me to assume Alvin would trust me when he did not know me. I knew I needed to get the lesson and not delay it another day. I decided to go to a convenience store down the street and withdraw money from the automated teller machine (ATM). I told Alvin and informed him I would be right back. Upon returning with cash in hand, Alvin and I sat down to begin our first lesson.

He began to teach me the basics, such as the names of the various pieces (e.g., queen, pawn) and how they are allowed to move on the board. We had side conversations throughout this first lesson, mostly me asking him a few questions about the park and himself. Toward the 
end of our lesson, he inquired about a textbook I had set on the table. I explained to him that I was in graduate school and it was the textbook for one of the courses I was teaching. As our first lesson came to an end, he knew a little about me as did I him. We made plans to meet again the following week. After I left the field this first visit, I remember feeling excited and proud by how well things had gone and was looking forward to subsequent visits.

For the next six months, I took lessons from Alvin multiple times a week. The lessons were of increasingly sophisticated strategies, such as which pawns to move and when to bring the queen out. I would occasionally forget something he taught me and he would make a comment, such as, "I told you this last time." He seemed slightly annoyed when I would forget, but he continued to instruct me.

Occasionally, Alvin would interrupt our lessons to play a game for money. The first time this happened, I was unaware that gambling was a common occurrence at the park. As a researcher, I wanted to learn more about this so I would always encourage him to play a money game if the opportunity presented itself. I made sure to emphasize that it would be educational for me to watch and it could help improve my game. I wanted to justify why we should stop my lesson without raising suspicion to my true research intentions.

Additionally, during our lessons, I used our time together to learn more about him. Playing chess allowed us the opportunity to have a casual conversation. Over time, we got to know each other better and I became more comfortable asking him questions about things he told me from his past, or about observations I made in the field. Alvin and I were forming a close bond and I was learning a lot about chess, but this relationship had problems, too.

An ongoing conflict between us concerned money. Alvin charged me $\$ 5$ for each lesson, which was a fair deal, given that they usually lasted one to two hours. After a while, however, 
Alvin began asking me for more than a proverbial tuition fee for the lessons. ${ }^{4} \mathrm{He}$ would take me aside or walk with me as I left the park, then ask for some extra money for a snack or coffee.

Early on, such monetary requests were rare and so not a problem to grant. Then they became routine. The more often Alvin asked for extra money, the more annoyed I became. I felt this was impolite, but, more importantly, I did not have money to give. I explained this to him, but Alvin persisted. He would even beg, saying I was better off than him. More often than not, I gave in, thinking that to do otherwise would upset Alvin and put my research in jeopardy. At the time, I was not confident enough in my standing at the park and I feared that if I refused his request, he might stop giving me lessons and deny my access at the park. I needed to be in his good graces, not only because he was my point of contact, but he had a lot of influence at the park. He was respected by the other players and they admired him for his level of play. In many ways, he had control over my access to the park.

To overcome this issue, I began only bringing $\$ 5$ in cash to the park, figuring Alvin could not expect to receive what I did not have. Yet, he was savvy enough to know the difference between what a person has on their person versus in a bank account. He began asking that we go to a nearby convenience store to purchase him a snack or drink with my ATM card. The first few times, I agreed, grudgingly. Then I worked up enough annoyance and courage to tell him to stop. Upon hearing my proclamation, Alvin's stated it was nice to have a little extra money. In turn, I backed down a little, saying it would be okay if an occasional occurrence, not a regular feature of our encounters. Though I was using him to make headway in my research, I felt as though I was being used as a walking, talking ATM. Perhaps this was an undue effect of my covert role as a researcher, but probably not given that overt researchers face the same problem. Scott, for instance, was often asked for extra cash by his participants-turned-recruiters, who were 
drug dealers and robbers of low economic status. Indeed, most any relationship marked by economic disparity is likely to produce requests for handouts. Like gaining access, there is no one right way to respond. It took me a long time to assert myself, but once I did, Alvin limited his requests for additional money. In return, I began bringing snack foods to the park (e.g., granola bars). Compared to one off purchases at the convenience store, it was cheaper for me to bring items I already had at home, giving me more of control over our give-and-take relationship.

\section{Alvin's Piece}

Alvin had become my primary contact at the park, which relates to the other major conflict between us. When I would show up at the park, the other players assumed I was looking for Alvin, so they would point me in his direction. I grew to know other players and vice versa, but, until Alvin disappeared (discussed below), the vast majority of my time was spent talking and learning from him. This was a methodological problem, potentially. Common sense tells us that one person, namely Alvin, is unlikely to perfectly embody the population of chess players. So long as I did not assume Alvin's background, motives, and behavior to be exactly like that of everyone else, I was on safe ground. However, the goal of my study was not to learn about Alvin per se; it was to learn about all of the players..$^{5}$

This problem stemmed from Alvin acting possessive of me. He disliked me talking with other players, as evidenced by him questioning me for speaking to them and reprimanding men who spoke to me. It is hard to say why he acted that way, there are probably multiple reasons. One possibility is Alvin felt special by "having" me. Being my teacher not only validated his status as the park's best player, but it also meant he had something the other men did not — the attention of a female. Many of the men at the park, as I would later find out, lacked an intimate 
relationship with a partner. In some sense, that was what I represented to Alvin - an element of intimacy he and the others were denied. This likely played into his tendency to "want me" to himself because it allowed him to stand out among the others as the one "with" the girl. It is also possible that our relationship was viewed by him as a sign of him being more "manly" than the other men who did not have the attention of a female.

Alvin expressed his possessiveness of me in ways I did not desire. Perhaps because Alvin wanted to make it clear I "belonged" to him, or, maybe it was truly his way of expressing affection, he went beyond traditional social boundaries one would expect of a teacher. He would call me "baby," hug me, kiss my hand, and make flattering but unwanted comments about my physical appearance. As with the money issue, I tolerated the sexual harassment because I feared doing otherwise could limit my access to the park and players. But that tolerance may have sent the wrong signal to Alvin, perhaps worsening his untoward behavior.

Additionally, Alvin's possessiveness of me may have been exacerbated by my identity as his mentoree. Like many professors, he may have disliked the feeling that his student was not fully engaged in the day's lesson. While lecturing, other players would stand around the table to make conversation with me. Alvin's facial expression turned to angry annoyance, and he would tell the conversationalists not to bother me.

Yet, Alvin was bothered by more than academic distraction. On one occasion, I arrived at the park, and before heading over to Alvin's table, I briefly stopped and spoke with other players. Upon seeing this, Alvin aggressively said to me, "Hey, why are you talking to him?" Another time, a player came over to Alvin's and my table and said hi. Alvin looked cross at him, to which the player said, "What? Am I not allowed to say hi to her?" 
Because of such incidents, the players learned that Alvin wanted me all to himself. This put me is in a tough position, both practically and academically. I wanted to speak with everyone at the park, but feared Alvin would consider this as an act of disrespect. Not only was I learning chess from him, but I saw my acceptance in the park as largely dependent on his acceptance of me. This became a cyclical process: I did not develop strong relationships with anyone but Alvin, so I relied on my relationship with him, who deterred me from gaining rapport with other players.

As the months went on, Alvin's possessiveness worsened. When players tried to interact with me, Alvin's words and facial expressions revealed increasing frustration. In turn, he suggested solving this "problem" by conducting lessons at a nearby coffee shop. From his perspective, that was a rational idea. He did not know my major reason for coming to the park was research. I could have told him about this, but I did not feel ready to do so. Instead, I gave other reasons why I wanted to continue playing at the park, such as not feeling bothered by the other players, enjoying being outside, and wanting to be able to observe the ongoing games in an effort to learn and improve my own techniques.

\section{Adjusting Moves}

Eventually, the possessiveness issue was resovled unexpectedly. About six months into the study, Alvin suddenly stopped going to the park. About a week after his dissapparence, a player told me that Alvin was out of town, with an unknown return date. Thereafter, each time I went to the park but did not see him, it seemed more likely that he was not coming back.

Despite Alvin's possessiveness, or maybe because of it, I felt lost at the park without him. I did not anticipate his disappearance and was unprepared for how to navigate this new terrain. My relationship with him was far from perfect, but I did not have much of a relationship with 
any other player. By trying to respect Alvin, I had put myself in a bad spot. I thought about giving up the research, but decided to keep going back to the park. Each visit, I checked to see if Alvin was back and, more importantly, get to know the other players.

After Alvin left, the other players would ask me if I wanted to challenge them to a game. Until this point, I had not fully realized that they now saw me as a player, too. In their eyes, it was odd for me to be there and not play chess. I knew why I was "really" at the park, but they did not. After spending months taking lessons, I became a common fixture of the scene. I grew to understand their culture and social norms and I obeyed the unwritten rules that guided the behavior. I was no longer seen as an outsider, but instead, a trusted member of their group. I would never truly be one of them, but they treated and accepted me as a player. Although hiding my research intentions was bad in ways (discussed below), them viewing me as a player showed that I had managed to overcome my outsider status.

After some prodding, I started to compete. This felt strange to me, as, until then, I had only played with Alvin. And I worried what Alvin would think when he got back. Maybe he would be upset that I was interacting with the other men and getting closer to them, or that I was learning about chess from someone else.

No matter what his reaction might turn out to be, my research depended on me playing with others at the park. This would be the best way to familiarize myself with them, and vice versa. Thus, over the following months I visited the park a few times a week to play and watch games. Because I was knowledgeable of chess, known at the park, and not guarded by Alvin, I was able, finally, to focus on observing - that is, listening and watching - to the things that had drawn me there in the first place. I learned about the players' identities in and outside the park, as well as how this affected their interaction and activities, including hustles and crimes. 
At this point, I began seriously considering how to tell the players about my research. This was still a secret; not so much a lie as less than the whole truth. My secretiveness increasingly weighed on my conscious. The players had become not only my subjects, but also my friends. I cared about them, and feared that not being totally open with them would hurt their feelings.

My covert identity also posed methodological challenges. ${ }^{6}$ I had to play chess with my left hand and take notes with my right, proverbially speaking. Even worse, I could not openly take any notes. Plus, I had to be careful about not asking the wrong questions, or too many questions. And there were times that it would have been best to put the game on pause and turn my attention to a noteworthy case, but this was precluded by my undercover identity. Therefore, when I would leave the field, I would write what I could about certain cases, recognizing that my notes might be thin or my inference incorrect due to my limited information. Later, after I observed subsequent events or developed a greater understanding about certain cases, I would make corrections or expand on thin sections. I would also make notes in my fieldnotes when I was unsure of something, or write general questions for myself to think about on following field visits. Doing this served as a guide when I was in the field and allowed me to gain information to better address the interpretations I was making in my fieldnotes. But, I knew I wanted to go public so I could ask in-depth and probing questions to better understand and interpret what I was observing.

Nine months into the project, I partially disclosed my research to the players. I told the players about wanting to do research on them, while leaving out that I had been doing this all along. This first came up with Damien. One evening, he asked me if I could help pay for his bus fare. I obliged and then decided this was a good time to ask for a favor in return. I briefly 
explained that I wanted to ask him some questions for a school assignment (at this point, my dissertation), to which he said, "Yeah, whatever you need." It could be asked if this approach was "ethical" in the sense that I used his financial request as a springboard for my academic request. The good and bad thing about "ethics" is none are universal, which is to say some readers may think it was wrong of me to do so. I would counter, though, the bus fare was not contingent on his participation; I would have given it to him even if he had declined.

After Damien agreed, I asked if he thought the other guys would feel the same way. Damien reassured me, "Yeah, we know you're cool. Just tell me what you need." This conversation gave me a great sense of relief. It also made me more confident to have a similar conversation with other players. In the coming weeks, I told them what I had discussed with Damien, using it as a springboard to gain their approval of the research, too. Word travled fast among the players and I quickly became known as the park's researcher.

\section{Sacrifice the Exchange}

Once I went public with my researcher identity, I learned that obtaining the players' cooperation would require me to "go with the flow": have an open, relaxed attitude toward the planning, timing, and completion of actions. Players thought this was an appropriate mode of conduct (see also Anderson, 1999), though people from another subculture may think of it as haphazard, rude, or inconsiderate. Imagine, for instance, the negative response of teachers to students who show up to class late and act as though nothing is wrong with their tardiness; ditto for romantic dates, weddings, job interviews, work meetings, and much more. Going with the flow was not an optimal strategy for me because it delayed my progress in the doctoral program. Without the necessary data, I was unable to move forward in a timely manner, which was consequential to graduating and getting a job. 
I had little choice but to abide by this code (see also the methodological chapter of Jacobs \& Wright, 2006). I was dependent on the players for information, but they did not need me. Thus, I had to have a loose approach toward making a research-oriented itinerary with players, and be tolerant when they did not show up as planned. In fairness to my participants, their absenteeism is not unique among research participants. Part of being an ethnographer is waiting around for persons who agreed to talk at a particular time and place (e.g., see Jacobs \& Wright, 2006). This is all the more frustrating when it is unclear if they are running late, and so you should wait, or not coming at all, in which case waiting is a further waste of time.

Despite not taking offense to players' broken promises, these often disappointed and frustrated me. This would result, for instance, when players did not show up for scheduled interviews. When commitments are not kept, it almost inevitably results in negative emotions. This is particularly true when the activities are important, such as, in my case, to completing a dissertation. I was easily affected by the players' lack of planning because I was not raised by the code of "go with the flow," which, again, prescribes a large degree of flexibility in when events take place. I am almost always present where and when I should be. Thus, I did not understand that this behavior was a cultural norm for the players.

Going with the flow is not all bad. After all, part of the logic behind this code of conduct is that an unplanned activity may turn out to be better than what could have been scheduled. Indeed, the notion of going with the flow meshes well with that of analytic induction: using data to continually refine what is being studied and the explanation of it (Katz, 2001). Part and parcel with that process is a fieldworker's task of figuring out what to observe and record. Ethnographers are not passive but active in this role, as it is impossible to attend to everything that goes on. 
Another positive example of going with the flow concerns the day I found out the park was unexpectedly shut down. A friend informed me there was a fatal stabbing at the park the night before. I immediately reached out to the players via text message to make sure they were okay. I quickly learned the park was closed. I was told by a park official that this could last up to three weeks, though it wound up lasting seven months.

By this point in my research, my goal was not only to learn about the park, but also the broader lives of players. The closure provided an opportunity for me to follow the players around as they relocated to other areas. Additionally, the shutdown served as a catalyst for many discussions with players. Perhaps because of their frustration with the closure, the players, some of which I did not have a strong rapport with yet, opened up to me in a way I had not anticipated. They shared details about the fatal stabbing and their reactions to how it was being handled, conversations that then branched off into other topics and provided me with a better sense of who they were.

Researchers often struggle with data to collect, to what extent, and whether they are missing something. This was true for me, but with experience, I grew more confident not only in how to make notes, but also what (not) to make them about. When I was in the field, my main method for taking jottings - short words and phrases that are later used to develop fieldnotes was through the use of my cell phone. I knew it would be unobtrusive as it is common, in almost any setting, to see someone on their phone. Therefore, I was able to use my phone and type notes without appearing suspicious. This allowed me to take jottings as events occurred, or soon thereafter. I would then expand on my jottings as soon as possible and make detailed fieldnotes.

As I spent more time at the park, the quality of my fieldnotes improved. In the beginning, my notes were thin and lacked the necessary depth and detail. This was due in part to the 
"newness" of conducting field observations. When I first started, everything was new and it was a sensory overload. This made it challenging to know what to look for or what was important. As I spent more time in the field, I became more aware and attune to my surroundings, got to know the players better, and developed an understanding of the social world of the park. Also, I gained greater access as my insider status improved, and this allowed for richer fieldnotes.

\section{Endgame}

I continued to collect data for four months after closure. At that point, the future of the park was unclear and I had looming graduate program deadlines. I had a sufficient amount of data, so Scott advised me to get going on writing the dissertation. For two years, I had continually learned about players as I gained rapport with them. At first total strangers, we grew to tease each other, share things on our mind, and confide in each other. I enjoyed spending time at the park, and appreciated the meaningful conversations and moments shared with them. However, the good things that came from the research raised problems, too.

As true in most any relationship, there were times that I had little desire to visit the players. Going to a scene is easy, but it is difficult to make the most of one's time there. It is mentally fatiguing to make observations, take jottings, be an active participant in the setting, and later write up extensive fieldnotes. There are various ways to keep going, however (see Emerson, Fretz, \& Shaw, 2011; Spradley, 1980). A practical example is making short- and long-term schedules with specific tasks (e.g., taking fieldnotes, writing them up, analyzing them, etc.) with specific deadlines (e.g., finish taking all fieldnotes and subsequent tasks). Motivationally, stay focused on the importance of data for telling people's stories. With that said, sometimes the best thing to do is take a vacation from the field. 
A researcher who sets out to do fieldwork should realize that it may come to dominate their life. I am but one of many ethnographers to whom this happened. Other ethnographers academically delve into a life with which they are already accustomed, be it personally or through friends and family (e.g., Boeri, 2017; Contreras, 2013). In either case, completing ethnographic research requires sacrifice. There is always a give and take between doing one thing versus another, but this is especially true of fieldwork because the researcher needs to be on the subjects' schedule - go with their flow. In my case, I often wound up prioritizing the players and park over class assignments, prepping courses I was teaching, and my personal life. When the project began, I could not have foreseen that the research would envelope my life.

During the course of fieldwork, the researcher is affected by the field and experiences a range of emotions as they become entangled in the lives of their subjects and invested in their well-being (Coffey, 1999). Such was true for me as I would occasionally try to help the players with their personal affairs, offering advice or gathering information for them. I frequently thought about them when I was not at the park and I found myself worrying about them, especially during cold nights when I knew some of them slept on the street. I would text message them to find out how they were doing, but, in reality, there was little more I could do for them.

I became part of a new social circle, but, ironically, this made me feel isolated among my academic peers. Not many graduate students in the department conducted ethnography and no one at the time conducted a field study to this extent. This uniqueness (among other issues) made it difficult for me to talk with other Ph.D. candidates about my research. I did not think they would understand my relationships with and concern for the players, in part because they were so different from my peers. All of this is to say that going native, or becoming a member of the group one is studying, can make a researcher feel like a stranger in their own world (O'Reilly, 
2009). No amount of talking with a colleague, mentor, or other outsider can fully attenuate such feelings. So a small piece of advice, then, for people who undertake this sort of research is to take solace in knowing we are alone together.

\section{Acknowledgements: TBA}

\section{References}

Anderson, E. (1999). Code of the street: Decency, violence, and the moral life of the inner city. New York, NY: W. W. Norton \& Company, Inc.

Anderson, E. (2011). The cosmopolitan canopy: Race and civility in everyday life. New York, NY: W. W. Norton \& Company, Inc.

Bernasco, W. (Ed.). 2010. Offenders on offending: Learning about crime from criminals. Cullompton, UK: Willan Publishing.

Boeri, M. (2017). Hurt: Chronicles of the drug war. Berkeley, CA: University of California Press.

Boeri, M., \& Lamonica, A. K. (2015). Sampling designs and issues in qualitative criminology. In H. Copes and J. M. Miller (Eds.), The Routledge handbook of qualitative criminology (pp. 125-143). New York, NY: Routledge.

Coffey, A. (1999). The ethnographic self: Fieldwork and the representation of identity. London, UK: Sage.

Contreras, R. (2013). The stickup kids: Race, drugs, violence, and the American dream. Berkeley, CA: University of California Press. 
Copes, H., Jacques, S., Hochstetler, A., \& Dickinson, T. (2015). Interviewing offenders: The active vs. inmate debate. In H. Copes and J. M. Miller (Eds.), The Routledge handbook of qualitative criminology (pp. 157-172). New York, NY: Routledge.

Copes, H., \& Miller, J. M. (Eds). (2015). The Routledge handbook of qualitative criminology. New York, NY: Routledge.

Duneier, M. (1999). Sidewalk. New York, NY: Farrar, Straus and Giroux.

Emerson, R. M., Fretz, R. I., \& Shaw, L. L. (2011). Writing ethnographic fieldnotes, (2 ${ }^{\text {nd }}$ ed.). Chicago, IL: University of Chicago Press.

Goffman, A. (2014). On the run: Fugitive life in an American city. Chicago, IL: The University of Chicago Press.

Goffman, E. (1963). Stigma: Notes on the management of spoiled identity. New York, NY: Simon \& Schuster, Inc.

Goode, E. (1999). Sex with informants as deviant behavior: An account and commentary. Deviant Behavior, 20, 301-324.

Jacobs, B. A. (1998). Researching crack dealers: Dilemmas and contradictions. In J. Ferrell \& M. S. Hamm (Eds.), Ethnography at the edge: Crime, deviance, and field research (pp. 160177). Boston, MA: Northeastern University Press.

Jacobs, B. A. (2006). The case for dangerous fieldwork. In D. Hobbs \& R. Wright (Eds.), The Sage handbook of fieldwork (pp. 157-168). Thousand Oaks, CA: Sage.

Jacobs, B. A., \& Wright, R. (2006). Street justice: Retaliation in the criminal underworld. New York, NY: Cambridge University Press.

Katz, J. (2001). Analytic induction. In N. J. Smelser \& P. B. Baltes (Eds.), International encyclopedia of the social and behavioral sciences (pp. 480-484). Oxford, UK: Elsevier. 
Liebow, E. (1967). Tally's corner: A study of negro streetcorner men. Lanham, MD: Rowman \& Littlefield Publishers, Inc.

Marx, G. T. (1989). Undercover: Police surveillance in America. Berkeley and Los Angeles, CA: University of California Press.

Miller, J., \& Palacios, W. R. (eds.). (2015). Qualitative research in criminology. New Brunswick, NJ: Transaction Publishers.

O’Reilly, K. (2009). Key concepts in ethnography. Thousand Oaks, CA: Sage.

Small, M. L. (2009). How many cases do I need? On science and the logic of case selection in field-based research. Ethnography, 10, 5-38.

Snow, D., \& Anderson, L. (1993). Down on their luck: A study of homeless street people. Berkley, CA: University of California Press.

Spradley, J. P. (1979). The ethnographic interview. New York, NY: Harcourt Brace Jovanovich.

Spradley, J. P. (1980). Participant observation. New York, NY: Harcourt.

Weiss, R. S. (1994). Learning from strangers: The art and method of qualitative interview studies. New York, NY: Free Press.

Wesley, J. K. (2015). Negotiating identity as a qualitative researcher: The impact of studying marginalized populations in criminology. In H. Copes \& J. M. Mitchell (Eds.), The Routledge handbook of qualitative criminology (pp. 144-156). New York, NY: Routledge. 
${ }^{1}$ Though this chapter is from my perspective, Scott Jacques, the second author, helped to write it and so is a coauthor. As touched upon throughout, Scott supervised my study. What it means for someone to be a "supervisor" greatly varies from person to person or project to project. Whereas some supervisors are very hands on and directive, Scott is exactly the opposite. For him, a dissertation is about establishing yourself as an independent scholar, so it has to be a road mostly travelled alone. He always made it clear to me and others that this is my project, not his, and thus its success or failure is my doing. I had final say on what people and phenomena to focus on, how and when to collect data in situ, write up fieldnotes, analyze them, etcetera. The guidance he did provide followed a few general principles: don't get hurt; don't violate our Institutional Review Board (IRB) agreement; otherwise, do what needs to be done to finish the project, to the best of your ability, in a timely manner. This book's editors, Drs. Boeri and Shukla, asked us to present details about what Scott thought and advised in certain situations, such as how I should handle conflict with Alvin (described below). Trouble is, Scott has little memory of these situations (i.e., they are not salient events in his mind). So rather than risk telling fictional accounts, we opted to let this story be seen through my eyes alone.

${ }^{2}$ On identity issues in conducting qualitative research, see Wesley, 2015.

${ }^{3}$ All subject names are pseudonyms.

${ }^{4}$ On money-based conflict experienced by other ethnographers, see, e.g., Duneier, 1999; Jacobs, 1998, 2006; Liebow, 1967.

${ }^{5}$ On how ethnographic sampling designs affect results, see Katz, 2001; Small, 2009.

${ }^{6}$ On the problems and prospects of various data recording techniques, see Emerson, Fretz, \& Shaw, 2011; Spradley, 1979, 1980; Weiss, 1994. 